\title{
From Periphery to the Core: Promoting College English Teachers' Professional Development From the Perspective of Community of Practice
}

\author{
Li Huiyin ${ }^{1}$ \\ ${ }^{1}$ Guangdong University of Foreign Studies, China \\ Correspondence: Li Huiyin, Guangdong University of Foreign Studies, China.
}

Received: July 13, 2019 Accepted: August 18, 2019 Online Published: August 20, 2019

doi: 10.5539/elt.v12n9p74 URL: https://doi.org/10.5539/elt.v12n9p74

\begin{abstract}
Collaborative lesson preparation is a common practice for Chinese teachers who work together to solve their teaching difficulties and problems. Based on the theoretical framework of community of practice (CoP), this paper describes how a teaching group in a university (entitled G University) in China was engaged in its lesson-preparation community and how the collaboration in lesson preparation impacted teachers' professional development. Based on the findings of the study some lessons have been drawn about how to establish a successful CoP to promote Chinese teachers' professional development.
\end{abstract}

Keywords: community of practice, collaborative lesson preparation, professional development

\section{Introduction}

As teachers matter most in student learning, high-quality professional development for teachers plays a key role in achieving the goals of any educational reforms (Borko, 2004) which not only raises expectations for students but for teachers too (Corcoran, 1995). Challenges from globalization, stunning technological innovations, and learning changes have determined that education in the $21^{\text {st }}$ century must be future-oriented and visionary. To meet these challenges, teachers should constantly upgrade themselves, acquire new skills, deepen their content knowledge, develop and master new teaching practices, which can all be encapsulated in the term of professional development. Without "ongoing and targeted professional development" (Borko, 2004, p. 3), changes in teachers and classroom practices are hard to bring about (Ball \& Cohen, 1999) and the fulfilment of ambitious goals set for students by educational reforms will be woefully thwarted.

Professional development has two major forms. According to Amit (2015), professional development refers to "skills and knowledge attained for personal as well as career development" (Ahuja, 2015, p. 11), encompassing facilitated learning opportunities in any forms, "ranging from college degrees to formal coursework, conferences and informal learning opportunities situated in practice". Coldwell (2017) defines professional development as "formal and informal support and activities that are designed to help teachers develop as professionals" (p. 189). Both state explicitly professional development are embodied in two forms: the formal and informal ones. Formal ones constitute a major component of the "training model" (Little, 1993, p. 129), or the "traditional view" (Lieberman, 1995, p. 591). In this model, teachers are the trainees assumed to acquire knowledge and new skills while trainers act as experts, decide, and deliver important information to be applied in the classroom (Feiman-Nemser, 2001). Examples of this training model are professional conferences, seminars, workshops, and training courses. Till now, they are still the most prevalent forms of professional development (Eurydice, 2008).

While formal professional development provides structured learning with a specific curriculum, informal learning opportunities do not follow any structured curriculum. Examples are self-study, classroom observations, action research as well as collaborative activities such as conversations with colleagues or parents, coaching, and mentoring (Coldwell, 2011). In this informal model, teachers are more than recipients of knowledge. Rather, they play an active role. They not only design the learning process, choose their learning contents, but decide their learning goals and methods independently (Richter, Kunter, Klusmann, Lüdtke, \& Baumert, 2011). Participation in this form is generally voluntary at teachers' own initiative (Eurydice, 2008).

Due to its importance in education, professional development is demanded and provided for teachers across the 
world. In America, acts such as the No Child Left Behind (NCLB) Act state or propose high-quality professional development for teachers. In China, Teacher Development Centers have been established since 2012 (Quan \& $\mathrm{He}, 2016)$ which provides teachers support and guidance to boost their development.

Despite these efforts, professional development for teachers has been criticized as being inadequate or ineffective (Corcoran, 1995). Constructivist theories in learning have driven teacher education researchers to question the effect of the training model. They argue that information delivery in the training model is "too top-down and too isolated from classroom realities" (Corcoran, 1995, p. 4), dismisses teachers' agency, and that the contents are usually fragmented (Putnam \& Borko, 1997), lacking "focus, intensity, follow-up, and continuity" (Corcoran, 1995, p. 4), therefore, has weak effects on teachers. Instead, they stress teachers' active and significant part in promoting their own professional development, which initiated the transformation of professional development paradigm from the training model to the learning model. Community of practice (CoP) comes into being and provides a platform for individuals to develop and share their expertise (McDermott, 1999).

The context of this study is situated in G University in China and focuses on how a group of college English teachers in G University interact with each other in their collaborative lesson preparation. Drawing on the theory of community of practice (CoP), this study describes how these teachers learn from each other's experiences and gain new insights into their teaching and learning.

\section{Community of Practice}

Community of practice (CoP) was first coined by cognitive anthropologist Jean Lave and educator Etienne Wenger (1991) in their co-authored seminal book entitled Situated learning: Legitimate peripheral participation. $\mathrm{CoP}$ is defined as "groups of people who share a concern, a set of problems, or a passion about a topic, and who deepen their knowledge and expertise in this area by interacting on an ongoing basis"(Wenger, McDermott, \& Snyder, 2002, pp. 4-5)). Different from cognitivist theories that view learning as an individual effort and argue that acquisition takes place inside the learner's mind predominantly in formal educational contexts, CoP focuses on informal and situated social interaction. It views learning as a "collective, relational, and social process" (Omidvar \& Kislov, 2014, p. 266). That is, CoP members learn and acquire identities via regular interactions with other human beings by "engaging in and contributing to the practices of the community"(Chen \& Cheng, 2014, p. 35) and with "artefacts such as books, computer programs, and documents" (Laksov, Mann, \& Dahlgren, 2008, p. 123).

Within the framework of CoP, learning occurs when a novice moves from "legitimate peripheral participation" (LPP) to full participation within a community. According to Wenger (1998), when newcomers comes into a community, their participation is at first legitimately peripheral. When they interact with old-timers, they pick up the skills as a member of the community in thinking, behaving, and speaking and gradually become more experienced in the practices that characterize the community. They not only learn explicit aspects of social practices, such as "language, tools, documents, images, symbols, ... codifies procedures, regulations" ( Wenger, 1998, p. 47), but implicit elements too, such as "relations, tacit conventions, subtle cues, untold rules of thumb, ... embodied understandings, underlying assumptions, and shared world views" (Wenger, 1998, p. 47). In light of $\mathrm{CoP}$, "being involved or participating actively and fully is learning" (Correa, Martínez-Arbelaiz, \& Gutierrez, 2014, p.450). As their participation increases both in intensity and complexity, they gradually become full members and their activities become more and more important and central to this CoP (Morrell, 2003). For this reason, CoPs are regarded as "the basics building blocks of a social learning system because they are the social containers of the competencies that make up such a system" (Wenger, 2000, p. 229).

Wenger, McDermott, and Snyder (2002) distinguish three levels of membership in and across a CoP: peripheral members, active members, and core members. Peripheral members contribute only sporadically to the community due to their lack of necessary abilities and knowledge. Newcomers usually start as peripheral members. Active members contribute to a community regularly and core members are those active members who also assume substantial responsibilities for the whole community and make efforts to influence its directions. Therefore, the learning process for newcomers is a process for them from being a peripheral member to being a core member.

In higher education, CoP model presents a viable approach to creating collaboration and development among its members through voluntary interactions. Since participants' roles and responsibilities are not assigned or defined formally, the delineations of member roles and participation are not clear (Probst \& Borzillo, 2008), which means hierarchical authority does not exist in a CoP (Wenger, 1998). In this way, CoP provides a safe environment where its members who possess a common impetus learn from and share with each other to traverse 
the limitations of conventional practices. The quality and quantity of practices that have been developed and exchanged within a COP promotes the members' professional development and a CoP doesn't cease with the accomplishment of one particular objective. It encourages communication, creates collaboration, reduces learning curves for newcomers, and promotes knowledge-building among its members (Howlett, Arthur, \& Ferreira, 2016).

Since its application in teacher professional development (Wenger, McDermott, \& Snyder, 2002), CoP has been proved effective for enhancing learning and teaching in higher education (Viskovic, 2006). CoP takes different forms and occurs in various contexts. In China typical forms of $\mathrm{CoP}$ for university teachers include a variety of activities held by Teacher Development Center in each higher education institution, teacher development forums and workshops by academic associations, teaching colloquium by colleges, saloons, self-initiated online chat groups, and reading clubs. In most cases, these CoPs are educational communities for in-service teachers. To higher education teachers who are puzzled and overwhelmed by continuous changes in education, workload, and research output demands (McDonald \& Star, 2006), CoP creates a space for professional conversations around and solutions to identified issues (McDonald \& Star, 2006)

According to Wenger (1998), a successful CoP is characterized by three principles: mutual engagement, joint enterprise, and shared repertoire (Wenger, 1998). Mutual engagement refers to members' interaction where they cooperate to develop norms and rules to guide the engagement process. Joint enterprise refers to the common goals of the CoP whose members share, understand and contribute to, while developing competencies through negotiation needed within the CoP. Shared repertoire is resources such as behavior, language, documents, and artefacts that belong to the community and all its members have access to and are competent in utilizing (Wenger, 1998).

What is noteworthy is individuals can participate within several CoPs (Handley, Sturdy, Fincham, \& Clark, 2006), making tensions and conflicts possible. Wenger (1998) explains that "we engage in different practices in each of the communities of practice to which we belong. We often behave rather differently in each of them, construct different aspects of ourselves and gain different perspectives" (p. 159). Borko (2004) proposes that "to understand teacher learning, we must study it within these multiple contexts, taking into account both the individual teacher-learners and the social systems in which they are participants" (p. 4).

\section{The Context of the Study}

G University has always been at the forefront of college English reforms in China due to its strong academic features and status among foreign languages universities. Years before the issuing of the latest version of College English Curriculum Requirements, G University has already established a rather integrated college English course system. Three major kinds of English courses for non-English majors have been offered to its on-campus students, including general English courses, English course for special purposes, and cultural courses (CC), which are also the three departments within College English School in G University. According to G University's teaching arrangements, the course of Classical Western Cultural Studies occurs in the fall semester and Modern Western Cultural Studies and Literature in the spring semester. As CC department takes in new members each year, a collaborative lesson preparation group is established for several purposes. One is to familiarize new members with their teaching and to replenish veterans with new perspectives and vitality, one is to ensure the quality of student learning, and the other is to make the $\mathrm{CC}$ an outstanding feature of the university. This is the joint enterprise of the CoP. New members or novices in this study are newly recruited teachers or veteran teachers who have been teaching for years but have not taught these two courses before. This study examined the $\mathrm{CoP}$ in the $\mathrm{CC}$ department in 2018 for one semester.

Altogether the CoP of $\mathrm{CC}$ is composed of ten teachers. Five of them have been teaching cultural courses for at least ten years, four are veteran teachers but have never taught these two courses, and one is a newly recruited young teacher. Among this teaching team, five of them are majored in literature and cultural studies, three of whom have been teaching this course for years, another three in linguistics, one in English education, and one in intercultural studies. It is obvious that peripheral members are not small in number, which makes this community significant. The course leader and two of the five veteran teachers are the core members because of their contribution to the community. The rest of the five veterans were the active members. Within this community, the core and active members help the rest to understand content knowledge better and deeper, share their teaching experiences and difficulties, create new teaching practices with newcomers via discussion and negotiation, and more importantly, promote their professional development.

\section{The Implementation of CoP}

Teacher collaboration is a common practice among Chinese teachers. It involves various teacher development 
activities on an institutional basis (Xu, 2012). Collaborative lesson preparation is one of the forms of teacher collaboration. There is no consensus as to the definition of collaborative lesson preparation. But it is generally acknowledged that collaborative lesson preparation is an important school- or college-based activity where teachers work together to exchange pedagogical experiences in lesson preparation, classroom management, and learning assessment (Gao \& Xu, 2014). It is done in an organized, prepared, and purposeful way where teachers of the same subject at the same grade convene at an appointed place. As a consequence, teachers feel more supported, less stressed, and more confident as they are well-prepared in how to handle potential challenges and difficulties in a collective way before class that may otherwise have to be confronted alone (Xu, 2013).

To a great extent, the collaborative lesson preparation in CC CoP in G University follows the procedure (see figure) suggested by Cerbin and Kopp (2011). After getting to know who the members were in the CC teaching team, the dean and the course leader informed the members of the establishment of a CoP and explained to them the significance of this CoP. Collaborative lesson preparation was held at least once a month and was usually sponsored by the dean and the course leader. What has to be noted is that lack of hierarchy within CoP is not equivalent to the lack of leadership. The hierarchical leadership exists to select a minority to make vital decisions "based on assumptions of people's powerlessness, their lack of personal vision and inability to master the forces of change..." (Senge, 1990, p. 340), while the inclusive, democratic leadership is based on individuals' capacity to influence the community rather than on a position of authority (Pearse \& Conger, 2003). Therefore, the democratic leadership is encouraged within $\mathrm{CoP}$ in order to create bonds between team members and enable them to interact with each other.

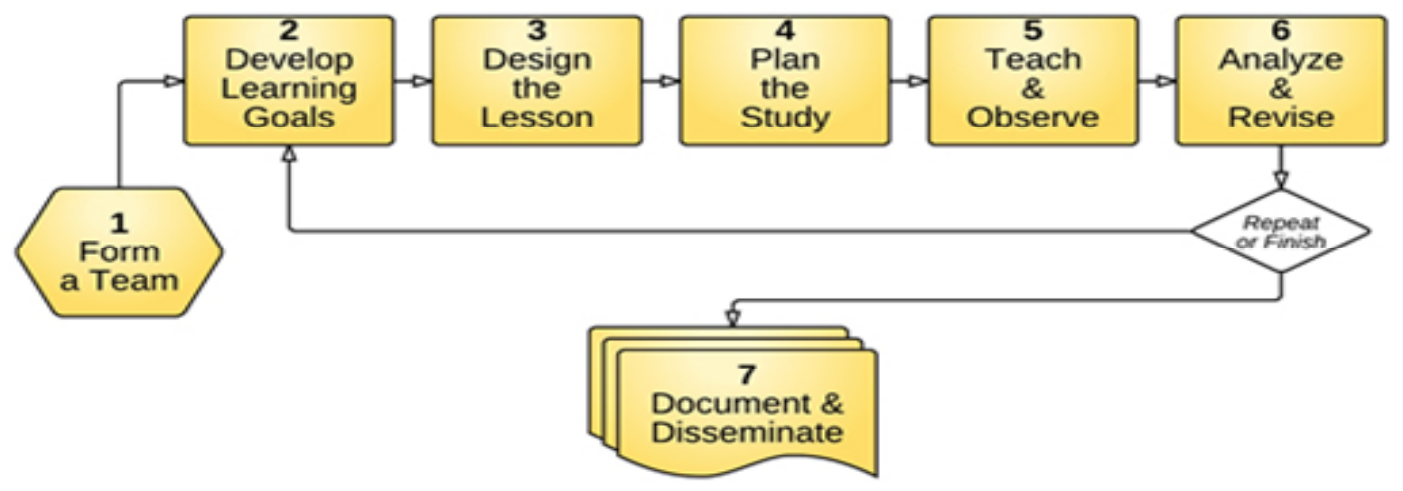

Figure 1. Lesson preparation CoP procedure borrowed from Cerbin and Kopp (2011)

The first meeting was particularly important. It occurred a week before the class so that all the members got a chance to share with and learn from each other. The course leader had already had an individual conversation with each member before the first meeting so that she could produce an outline of teaching plan and schedule for group discussion as well as be acquainted with each member and their problems beforehand. The syllabus drawn in the previous year was presented as a reference for revision. The sponsors (the dean and the course leader) would emphasize that this community was to develop the best teaching practices and that no one would be judged by their mistakes, naive questions, lack of information in their content knowledge. In the subsequent meetings they would reemphasize this point so that a safe and hierarchy-free learning zone was established for its members. The first meeting usually focused on revising the syllabus including the learning goals, teaching contents, teaching methods and plan, and assessment. All members had an opportunity to share their views based on their learning and teaching experiences and expectations. This communal discussion collaboratively helped to create a final version of the syllabus. Concerns coming from novices were discussed, which was made use of by the dean and the course leader as an opportunity to activate veteran members to "boost the intensity of the knowledge exchanges within the CoP" (Probst \& Borzillo, 2008, p. 340). As for the specific lesson plan for each topic, it was focused on in subsequent lesson preparation meetings, including instructional activities, assignments, and assessment. Besides, observation was encouraged within the CoP.

It was agreed that $\mathrm{CoP}$ would convene once a month. It came in good timing as each unit needed around a month to finish. Each time the CoP members met, they had just finished one unit and were to start another one. It was a perfect time for reflection and preparation too. Within the CoP, all members reflected, analyzed and shared how 
to revise their teaching and prepare for the new unit. These activities updated CoP members on all the good practices and informed them of how to adjust the learning objectives and syllabus for the next unit or next year. After that the course leader would set up a portfolio to store these practices, supplementary materials, and relevant documents as the shared repertoire for its members.

In mutual engagement, veteran teachers played a significant role in the community. In the CoP, the veteran teachers were the ones who shared their teaching methods, schedules, instructional activities, and problems first. Taking into consideration Chinese characteristic modesty and creating a democratic atmosphere within CoP, these veteran teachers would begin with "Though I have been teaching for years, I still think something can be improved. I would like to share with you what I have done so that you can help me to update my skills and understanding." They would also end their sharing with "That is what I have done. I wonder whether anyone could offer some good ideas or questions." In answering other members' questions, they would often use "I prefer to do so because..."in a negotiating manner. What's more, the old-timers also helped novices to understand the difficult parts both in contents and in teaching. Sharing also provided a good chance for the old-timers to reflect their teaching.

Toward the old-timers' sharing, novices usually showed their appreciation and gradually established their peripheral identity through sharing and asking questions. From questioning to clarifying their questions to in-depth learning, novices went beyond peripheral participation and came closer towards the core. For example, Greek mythology is one of the units in Classical Western Cultural Studies. This unit talks about Olympic gods, goddesses, and heroes with very complicated names and relations with each other, which Chinese students find very confusing. One old-timer shared what she did in this part. She presented a collocation exercise where students were asked to match each god with a company specialized in one domain. Another experienced teacher but new to this course suggested changing the exercise to another form and asking students to name a list of new companies. Another newcomer provided another exercise. She decided to present students with pictures from Greek mythology and ask them to tell each other the stories of those pictures. Moreover, some novices came up with other ideas, such as asking students to name products and to produce an ad trailer for their products. All the members liked these ideas as they could relate Greek myths with real life, familiarize students with the names of gods and goddesses, but also help them realize the significance of their study. In these exchanges and discussions, the peripheral identity of novices began to change.

Naturally, not all communications went peacefully. Conflicts and disagreement also existed. Due to divergent experiences and cognition, colleagues would hold different ideas about teaching and learning. For example, those interested in politics would like to introduce to class the hot topics in world affairs and organize students to discuss international issues from cultural perspectives. Some teachers challenged this idea and argued that students' cognition and language proficiency were not sufficient to support their discussion or present their ideas well of these topics. They doubted whether students would like these activities. Disagreements like this usually reminded teachers of something they may have ignored so that they could design their teaching according to their students' need and English level. But ideas and practices shared at collaborative lesson preparation helped its members to understand syllabus and teaching contents better, developed their thinking, and contributed to knowledge innovation.

\section{Impact on Teacher Development}

Collaborative lesson preparation impacted the members within the CoP differently. But all felt its positive impact. One old-timer shared at the meeting what she benefited from this CoP.

It is not easy to be a teacher. Teaching is not a multiple choice with only one standard answer. You should allow and welcome interpretations and analysis from different perspectives. This course is aimed at helping students understand western culture in politics, religion, history, education, and in other fields, to help them know how to make comparisons with Chinese culture, and to cultivate their cultural awareness, creativity and critical thinking. Collaborative lesson preparation contributes to the fulfilment of this goal by widening and deepening my thinking, updating myself on practices and knowledge, and enhancing my competences not only in teaching, but in many other fields we expect our students to develop (Member 1, at the lesson preparation meeting).

Another old-timer said: "Each collaborative lesson preparation is a bumper harvest. We share our ideas with sincerity and make good use of the information we receive in our discussion, which clarifies our doubts and problems and improves our teaching. (Member 2, at the lesson preparation meeting)."

The brand-new colleague shared her thoughts in the following way:

I remembered very well how I felt when I was asked to join this teaching team. When I had a look at the 
textbook and the teaching plan on the first day, I was depressed. I had no idea how to teach this course. I was so nervous that I couldn't sleep well. I was worried about my first teaching day, and my second. Honestly speaking, I was in a low spirit almost every day. I haven't learned these topics when I was a student. They are new, hard, and too profound even for me. I spent hours in reading but couldn't understand it well. I cannot image how to teach students in a week. I asked myself how I could survive. Collaborative lesson preparation saved me. I love it. It filled up the gap in my knowledge bank, widened my horizon, and prepared me with necessary skills and knowledge. I didn't realize English classes can be conducted in such a way. How fun it is! It helped me to overcome my fears and worries and now I love teaching this course (Member 3, at the lesson preparation meeting).

Another newcomer commented by saying: "The help experienced teachers offered and the communication we had with each other helped us to master the key parts of each lesson within a short time, therefore, it increased our efficiency. With collaborative lesson preparation, I accomplished my teaching successfully this year. Collaborative lesson preparation made me feel I was back at the university as a student (Member 4, at the lesson preparation meeting)."

Another novice teacher reflected:

What you (another teacher) talked about last time set me into thinking. I should say you inspired me. I came to realize what you mentioned was so critical to our course. Discussion is a common class activity, but each discussion should be based on a clear learning objective. Our course is different from General English which has a very clear goal. Our course does not. But if each teacher is really clear about what we are going to discuss today, I think he/she should, first of all, be clear about the learning objectives. The major challenges for us are to find out these learning objectives and goals in the aspects of thinking, affection, and language for students among piles of piles of learning materials and make these objectives coherent, relevant, and tangible. I have tried to do so in this semester and have gained somewhat different perceptions of this course. I was not as nervous and worried as before, because I knew I was closer to my teaching goal (Member 5, at the lesson preparation meeting).

Another member said: "Collaborative lesson preparation helped me to anticipate how students will perceive, interpret, and construe the learning contents and activities. In this community I learned how to be a good, better, and best director in the classroom (Member 6)."

It is seen from these comments that they felt positive about this $\mathrm{CoP}$ and that this $\mathrm{CoP}$ was successful. It was in this CoP that members learned from each other, helped each other, overcame their fears and difficulties, and promoted their cognition and practice. It was in this CoP that they moved from periphery to the core.

\section{Conclusion}

$\mathrm{CoP}$ has become popular nowadays in universities. Some are very successful, others are not. This study describes how a teaching group formed and operated a $\mathrm{CoP}$ focusing on improving its teaching quality and promoting its members' professional development. Several lessons can be drawn from this study about implementing a successful CoP. First is a strong leadership. It is often misconstrued among university teachers that a CoP is a loosely structured and hierarchy-free community. Without hierarchy, participation is not required, and members can participate of their own volition. It may be true, but full membership is hardly achieved without sufficient and intense participation. Therefore, a strong leadership is needed. A leader should be able to align objectives with activities and adapt to the CoP members' specific needs so that members feel their participation in the COP is meaningful. If a leader can activate the connections and motivate the collaborations in this way, CoP can attract its members, engage them actively, and increase the "knowledge flows'density" (Probst \& Borzillo, 2008, p. 340). In this study, the dean and the course leader played such a role so that each member felt satisfied with the CoP.

Secondly, CoP should create an informal and risk-free space so that its members feel safe and willing to convey, to explore, and to test new ideas and new knowledge. If a mistake or disagreement will not bring about any penalty or shame, learning and innovation will be higher.

Thirdly, Cop is not a silver bullet but a platform to promote teacher learning. Members should adapt the collaborated lesson plans to varied student need and use them flexibly. Otherwise student need will be ignored, and all the lessons will be the same across classrooms. CoP should remind its members not to rely on collaboration too excessively, but to innovate. Otherwise they will lose their autonomy.

Fourthly, to maintain excitement within the CoP, external experts can be invited either in meetings or in observation. Experts usually provide focused approaches and rich knowledge content, which can improve CoP 
members' pedagogy and content knowledge. Besides, interactions with experts can stimulate creativity and generate new perceptions and ideas.

\section{Acknowledgments}

This study was funded by Guangdong Planning Office of Philosophy and Social Science, Guangdong Province (GD16XWW32). I feel grateful to the anonymous reviewers, the editors for their insightful comments, and to the colleagues who shared their invaluable opinions generously.

\section{References}

Ahuja, A. (2015). Professional development of teachers. Educational Quest, 6(1), 11-15. https://doi.org/10.5958/ 2230-7311.2015.00002.1

Ball, D. L., \& Cohen, D. K. (1999). Developing practice, developing practitioners: Toward a practice-based theory of professional educa- tion. In L. D.-H. \& G. S. (Eds.), Teaching as the learning profession (pp. 3-31). San Francisco, CA: Jossey-Bass.

Borko, H. (2004). Professional development and teacher learning. Educational Researcher, 33(8), 3-15. https://doi.org/10.3102/0013189X033008003

Cerbin, W., \& Kopp, B. (2011). Lesson study guide.

Chen, C. W., \& Cheng, Y. (2014). Learning from Team Teaching and Beyond: A Case Study on EFL Teachers' Professional Development. Pan-Pacific Association of Applied Linguistics, 18(1), 33-47.

Coldwell, M. (2017). Exploring the influence of professional development on teacher careers: A path model approach. Teaching and Teacher Education, 61, 189-198. https://doi.org/10.1016/j.tate.2016.10.015

Corcoran, T. B. (1995). Helping teachers teach well: Transforming professional development. CPRE Policy Briefs. https://doi.org/10.1037/e383832004-001

Correa, J. M., Martínez-Arbelaiz, A., \& Gutierrez, L. P. (2014). Between the real school and the ideal school: Another step in building a teaching identity. Educational Review, 66(4), 447-464. https://doi.org/10.1080/ 00131911.2013 .800956

Eurydice. (2008). Levels of autonomy and responsibilities of teachers in Europe. Brussels: Author.

Feiman-Nemser, S. (2001). From preparation to practice: Designing a continuum to strengthen and sustain teaching. Teachers College Record, 103(6), 1013-1055. https://doi.org/10.1111/ 0161-4681.00141

Gao, X., \& Xu, H. (2014). The dilemma of being English language teachers: Interpreting teachers ' motivation to teach , and professional commitment in China's hinterland regions. Language Teaching Research, 18(2), 152-168. https://doi.org/10.1177/1362168813505938

Handley, K., Sturdy, A., Fincham, R., \& Clark, T. (2006). Within and beyond communities of practice: Making sense of learning through participation,identity and practice. Journal of Management Studies, 43(3), 641-653. https://doi.org/10.1111/j.1467-6486.2006.00605.x

Howlett, C., Arthur, J. M., \& Ferreira, J. A. (2016). Good CoPs and bad Cops : Facilitating reform in first year assessment via a community of practice. Higher Education Research \& Development, 1-14. https://doi.org/10.1080/07294360.2015.1137881

Laksov, K. B., Mann, S., \& Dahlgren, L. O. (2008). Developing a community of practice around teaching: A case study. https://doi.org/10.1080/07294360701805259

Lave, J., \& Wenger, E. (1991). Situated learning: Legitimate peripheral participation. Cambridge, UK: Cambridge University Press. https://doi.org/10.1017/CBO9780511815355

Lieberman, A. (1995). Practices that support teacher development. Phi Delta Kappan, 76, 591-596.

Little, J. W. (1993). Teachers' professional development in a climate of educational reform. Educational Evaluation and Policy Analysis, 11(2), 129-151. https://doi.org/10.2307/1164418

McDermott, R. (1999). Why information technology inspired but cannot deliver knowledge management. California Management Review, 41(4), 103-117. https://doi.org/10.2307/41166012

McDonald, J., \& Star, C. (2006). Designing the future of learning through a com- munity of practice of teachers of first year courses at an Australian university. In The first inter-national LAMS conference: Designing the future of learning.

Morrell, E. (2003). Legitimate peripheral participation as professional development: Lessons from a summer 
research seminar. Teacher Education Quarterly, 30(2), 89-99.

Omidvar, O., \& Kislov, R. (2014). The evolution of the communities of practice approach: Toward knowledgeability in a landscape of practice. Journal of Management Inquiry, 23(3), 266-275. https://doi.org/10.1177/1056492613505908

Pearse, C. L., \& Conger., A. (2003). Shared leadership: Reframing the hows and whys of leadership. Thousand Oaks: Sage Publications.

Probst, G. ., \& Borzillo, S. (2008). Why communities of practice succeed and why they fail. European Management Journal, 26(5), 335-347. https://doi.org/10.1016/j.emj.2008.05.003

Putnam, R. \& Borko, H. (1997). Teacher learning: Implications of new views of cognition. In B. J. Biddle, \& T. L. Good (Ed.), The international handbook of teachers and teaching (pp. 1223-1296). Dordrecht, The Netherlands: Kluwer. https://doi.org/10.1007/978-94-011-4942-6_30

Quan, L. T., \& He, H. Z. (2016). Woguo Gaoxiao Jiaoshi Fazhan Zhongxin de Jianshe Licheng yu Pingjia [The construction and the evaluation of teacher development centers in China's higher education]. Higher Education Exploration, 5, 118-123.

Richter, D., Kunter, M., Klusmann, U., Lüdtke, O., \& Baumert, J. (2011). Professional development across the teaching career: Teachers ' uptake of formal and informal learning opportunities. Teaching and Teacher Education, 27(1), 116-126. https://doi.org/10.1016/j.tate.2010.07.008

Senge, P. (1990). The fifth discipline: Strategies and tools for building a learning organisation. London: Nicholas Brealey.

Viskovic, A. (2006). Becoming a tertiary teacher: Learning in communities of practice. Higher Education Research \& Development, 25(4), 323-339. https://doi.org/10.1080/07294360600947285

Wenger, E., McDermott, R., \& Snyder, W. (2002). Cultivating communities of practice: A guide to managing knowledge. Cambridge, MA: Harvard Business School Press.

Wenger, E. (1998). Communities of practice: Learning, meaning, and identity. New York: Cambridge University Press.

Wenger, E. (2000). Communities of practice and learning systems. Organization, 7, 225-246. https://doi.org/ $10.1017 / \mathrm{CBO} 9780511803932$

$\mathrm{Xu}, \mathrm{H}$. (2012). Imagined community falling apart: A case study on the transformation of professional identities of novice ESOL teachers in China. TESOL Quarterly, 46(3), 568-578. https://doi.org/10.1002/tesq.42

$\mathrm{Xu}, \mathrm{H}$. (2013). Exploring the institutional and professional role cognitions of EFL teachers in junior high school. Beijing: Foreign Language Teaching and Research Press.

\section{Copyrights}

Copyright for this article is retained by the author(s), with first publication rights granted to the journal.

This is an open-access article distributed under the terms and conditions of the Creative Commons Attribution license (http://creativecommons.org/licenses/by/4.0/). 